\title{
4 The potential of art and design for renewable economies in the Arctic
}

\author{
Timo Jokela, Glen Coutts, Ruth Beer, \\ Svetlana Usenyuk-Kravchuc, Herminia Din, \\ \& Maria Huhmarniemi
}

\section{Introduction}

In this chapter, we discuss some of the ways in which art and design practices might help to support and develop renewable economies in the Arctic. We use the term Arctic Art and Design (AAD) to refer to contemporary art, design, and media productions aiming to contribute to renewable economies and sustainable development in the particular context of the North and the Arctic. The sustainable development of the Arctic is defined in a variety of ways for different purposes and occasions (Fondahl \& Wilson, 2017; Gad, Jacobsen, \& Strandsbjerg, 2019; Stephen, 2018; Tennberg, Lempinen, $\&$ Pirnes, 2019). The dimensions of sustainability in this context include cultural and social sustainability, which means that the contemporary renewable productions must respect cultural diversity and heritage and must be produced in collaboration with local inhabitants, so that the economic benefits are shared with the region. Various aspects and examples of AAD have been studied in the research projects conducted in the Arctic Sustainable Arts and Design (ASAD) network at the University of the Arctic (ASAD, 2019; Jokela \& Coutts, 2018). In this chapter, we use this concept to describe art, crafts, design, and cultural productions that transmit the heritage of Arctic nature and culture. It is not limited to Indigenous art, instead, it also covers non-Indigenous arts and their liminal productions such as industrially produced craft-based products (Jokela, Huhmarniemi, \& HautalaHirvioja, 2019). We use the concept of AAD to highlight the view of art, design, and crafts as interwoven with one another and as an integrated part of the eco-social culture in the North (Härkönen, Huhmarniemi \& Jokela, 2018; Jokela, 2017). The idea follows the concept of duodji, which sees Sámi art, craft, and design as the union of expression, production, and way of living (Guttorm, 2015). In addition, the concept of AAD carries the idea of applying arts to societal and economic needs (Huhmarniemi \& Jokela, 2019; Jokela, 2013) and combining the methods of socially engaged art and service design (Härkönen \& Vuontisjärvi, 2018; Jokela \& Tahkokallio, 2015). AAD as the creative renewable economy can be seen as one of the Arctic models of smart specialisation on green economy and as a model to 
aim to economic and social resilience in rapidly changing Arctic regions (Giacometti \& Teräs, 2019; Woien, Kristensen, \& Teräs, 2019).

As industries traditionally associated with the Arctic region, such as largescale resource extraction and global exploitation of finite natural resources, are increasingly seen as unsustainable, we applaud the move toward more sustainable business practices. We argue that the creative industries, and art and design in particular, can play a central role in developing new, more sustainable business opportunities that benefit the economy while preserving and promoting more local, place-based, and renewable business practices. The underpinning philosophy of AAD is closely related to that of the cultural and creative industries (Hesmondhalgh, 2007) or, as described by Howkins (2001), the creative economies. According to Howkins (2001, pp. 88-117), the creative economy comprises advertising, architecture, art, crafts, design, fashion, film, music, performing arts, publishing, research and development, software, toys, and games, TV and radio, and video games. Writing almost a quarter of a century ago, Landry and Bianchini (1995, p. 4) contended that "the industries of the twenty-first century will depend increasingly on the generation of knowledge through creativity and innovation." The economic impact of the creative industries has been measured on worldwide by United Nations Conference on Trade and Development (UNCTAD, 2018), and in Nordic Arctic countries (Olsen et al., 2016) and has been found to exceed that of the driver industry. The creative economy report by United Nations Conference on Trade and Development (UNCTAD, 2018) concluded: "The creative economy is recognized as a significant sector and a meaningful contributor to national gross domestic product. It has spurred innovation and knowledge transfer across all sectors of the economy and is a critical sector to foster inclusive development." In this report, both creative goods or products and creative services are subsumed under the term "creative economy." The discourse of potential of the creative economy started, and still is, mainly connected to urban cities, centers, and innovation hubs.

Few articles and studies have characterised the processes of creative economy development in the Arctic and hardly any of them specialised to the field of art and design (Nordic Councils of Ministers, 2018; Olsen et al., 2016; Petrov, 2014, Petrov, 2016, Petrov, 2017). The discussion is often focused on the challenges creative economies face under limiting factors such as the exploitation of nature at the core of the Arctic economy, population decline, high economic costs due to long distances, and the globalisation of the Arctic region. For example, crafters in Lapland are said to be lifestyle entrepreneurs and microentrepreneurs who give priority to artistic work and hesitate to step into business-oriented work, for example, with the tourism field (Kugapi, Huhmarniemi \& Laivamaa, Forthcoming, 2020). Opportunities for renewable economies are hardly discussed, and the material and cultural heritage of the Arctic, commonly connected with Indigenous crafts and the skillful use of natural materials, has not been 
recognised as having the potential to make significant contributions to the economy, although we argue that this is now changing.

Our AAD model focuses on the economic potential of renewable natural and cultural resources that are plentiful in the Arctic. The notion of ecosystem services (ES) is central to our thinking (Milcu, Hanspach, Abson, $\&$ Fischer, 2013). ES focus on the use of nature, its conservation, and its social, cultural and economic relation to the Arctic. In addition to ES, such as water, wood, fibers, and food provisions and their use as new renewable bioeconomy (Teräs et al., 2014), the concept also includes cultural ecosystem services (CES), that is, the "non-material benefits obtained through spiritual enrichment, cognitive development, reflection, recreation, education, and aesthetic experiences" (Millennium Ecosystem Assessment, 2005, p. 4). Even when these cultural values are included in ES typologies, cultural, experiential, and other non-material values have generally received less attention compared to monetary and ecological values. Only a few studies, among other Chan, Satterfield, and Goldstein (2012) and Daniel et al. (2012), have paid attention to the cultural aspects of CES.

In this study, we will fill the gap by investigating the potential of art and design as renewable economies using the concepts of CES, and placemaking as our theoretical and practical framework. Drawing on some of our own research and development projects, we present four cases that illustrate the ways in which AAD can be a contributor to a creative renewable economy. Our examples are from Alaska (United States), Canada, Finland, and Russia. We will share our experiences and findings and suggest future lines of enquiry.

\section{Cultural ecosystem services and place-based development as conceptual framework}

The authors of this chapter have been collaborating on the research and development of wide-ranging themes in AAD for many years. The ASAD research and development network, which was founded in 2011, has been instrumental the development of this innovative work (ASAD, 2019). Since its inception, ASAD has sought to "identify and share contemporary and innovative practices in teaching, learning, research and knowledge exchange in the fields of arts, design and visual culture education" (ASAD, 2019; Jokela \& Coutts, 2018b). The organisation is one of the thematic networks of the University of the Arctic that aim to "foster issues-based cooperation within networks that are focused but flexible enough to respond quickly to topical Arctic issues" (University of the Arctic, 2019).

Among ASAD members, there has been emerging an interest in CES, and we believe that in the rapidly changing Arctic, discussions on CES can be used to weigh the balance between the use of nature, its conservation, and the social, cultural, and economic relations in the Arctic. According to the study by Milcu et al. (2013), mobilising CES as binding elements 
between social and ecological conceptual constructs is the core idea of the sustainability ideal. Hearnshaw and Cullen (2010) point out that thoroughly accounting for CES will be helpful in balancing primarily economic considerations and facilitate a more inclusive socio-ecological approach by exploring the interactions between social, ecological, and economic processes.

We know that in a global world, all cultural values in art and design may have little direct dependence on ecosystems, but we argue an especially significant relationship between ecosystems and the fulfillment of human needs can be demonstrated in Arctic CES.

We see that CES offer a theoretical and practical framework to think differently about the ways in which creative entrepreneurs may collaborate with communities using local natural, cultural, and social resources. Such collaboration, of course, must be undertaken in a way that is sensitive to and respectful of the unique nature, culture, and heritage of the Arctic and takes into account megatrends such as climate change, globalisation, and urbanisation (Nordic Council of Ministers, 2011; Stephen, 2018.)

In our thinking about AAD, CES are closely connected to place-based strategy, which is also known as place-making and can also be understood as an economic development strategy. It is the practice of using places and a community's capacities to make economic progress (Milone \& Ventura, 2010; Vodden, Gibson, \& Baldacchino, 2015). Building on existing strengths, this approach focuses on CES and the unique features of particular places to boost existing businesses and create new ones and even attract new investment. According to Daniels, Baldacchino, and Vodden (2015), place-based strategy is a reaction to conventional top-down, single-sector, nationalstage development projects. Thus, place-making can also be understood as an identity policy of remote, rural and peripheral places that are centers for their inhabitants.

We are also familiar with the criticism of utilising CES in art and design and in the discussion of the creative economy. Spiritual and aesthetic cultural values are not best captured by instrumental or consequentialist thinking and they are grounded in conceptions of nature that differ from the ES conceptual framework (Cooper, Bardy, Steen, \& Bryce, 2016). The different attitudes toward the use of CES can sometimes be quite passionate, since they are tightly bound to human values and behavior as well as social and cultural institutions and economic and political organisations. In the Arctic, they are also bound to Indigenous and non-Indigenous issues and relations.

An important factor is the effect of the diversity of ES to the diversity of Indigenous and non-Indigenous cultures in the North and the Arctic. Ecosystems influence the types of social relations that are established in particular cultures. The social relations in fishing societies, for example, differ in many respects from those in nomadic reindeer herding or non-Indigenous agricultural societies. According to Stephen (2018), the climate crisis has caused changes in harvesting, hunting, and fishing cultures, which has had a wider impact on cultural identities and traditional knowledge. In other 
words, the climate crisis has brought about changes in the ecosystems and has had effects on socio-economic and political realities, which has affected the cultures and self-understanding of Arctic Indigenous populations. We argue this is the case in many non-Indigenous communities in the North and the Arctic as well.

Besides material and social relations, Indigenous cultures of the Arctic add spiritual and religious dimensions and values to ecosystems. This calls for a certain cultural sensitivity in approaching Arctic art and design activities. Most often, it is commercial design productions and items that represents identities (for example, clothing) that cause heated discussions on cultural appropriation and exploitation. Visual symbols such as patterns and ornaments have significance in the continuation of cultures and even the sharing of world views (Joy, 2019; Kramvig \& Flemmen, 2019; Minnakhmetova, Usenyuk-Kravchuk, \& Konkova, 2019; Schilar \& Keskitalo, 2018). Thus, seeing Indigenous cultural traditions as an economic resource can cause tensions (Olsen et al., 2019 forthcoming; Smith, 1999). However, if members of Indigenous peoples themselves are participating in the transformation of tradition into contemporary and economic products, then there is less or no criticism. For example, the Sámi people were invited to collaborate in the production of the Disney film Frozen 2, which depicts Sámi culture.

In our review of the studies and articles dealing with CES, we have seen that the majority of these articles have been published in ecological journals. From an art and design point of view, this may be a partial explanation for the rather vague discussion of the creative industries or art and design in most of the examined articles. On the other hand, however, art history research has shown that even when the concept of CES is not in use, nature still provides a rich source of inspiration for arts, design, craft, media, and architecture, especially in the Arctic (Mäkikalli, Holt, \& Hautala-Hirvioja, 2019). The way nature inspires artists, can be seen to CES.

Besides art, many people find aesthetic, expressive, and emotional values in various aspects of ecosystems. For example, people value landscapes that are known for their beauty or the "sense of place" that includes locally and culturally significant stories and heritage (Hølleland, Skrede, \& Holmgaard, 2017; Lindhjem, Reinvang, \& Zandersen, 2015). These can all be connected to renewable creative industries because they affect where people choose to go to spend their leisure time or improve their well-being. CES plays an important role in nature, ecological, and cultural tourism and recreation, which is often supported, represented, advertised, and made know by means of the creative industries (de la Barre et al., 2016; Müller \& Viken, 2017; Rantala et al., 2019). When considering creative services as art and design products and goods, we see many opportunities for collaborations between art and design and tourism as renewable economies in the Arctic.

The following four case studies will demonstrate how art and design can play a role in cultural sensitive place-based renewable economies based on CES around the North and the Arctic. 


\section{Isuma: A lens to Canada's North}

Canada is known for its abundance of natural resources and empty wilderness, seemingly ready for the taking. However, basing the economy on resource extraction such as mining and fossil fuel-related industries so prevalent in the Arctic is not sustainable. In order to protect the balanced ecosystems of both humans and non-humans, there is a growing need for the development of alternative and diverse economies more aligned with sustainability, in relation to both the environment and the well-being of communities and culture in the North (Schott, 2016). In many examples, CES literature refers more to recreational or touristic values, rather than a deep engagement with what the concept of culture means (Ihammar \& Pedersen, 2017). Meanwhile, in Igloolik, Nunavut, the artist collective Isuma demonstrates the potential of cultural initiatives and renewable economies, using the concepts of ES, particularly CES, and place-making, while honoring their material and cultural heritage (Big River Analytics, 2017).

As Canada's first Inuit video-based production company, Isuma has a surprisingly long history (Kunuk, 2019). Co-founder Zacharias Kunuk began exploring the possibilities of the film almost three decades ago, when he used the profits from selling his traditional soapstone carvings to purchase his first video camera. This technology introduced him to new possibilities of storytelling, highlighting the life and landscape of the North, and in 1990 Kunuk and his collaborators, Paul Apak Angilirq and Norman Cohn, created Isuma Productions.

Since its inception, Isuma has produced a number of feature films, documentaries, TV series, and short films, including Atanarjuat: The Fast Runner (2001), The Journals of Knud Rasmussen (2006), Before Tomorrow (Le jour avant le lendemain) (2008), and One Day in the Life of Noah Piugattuk (2019), based on the landscape and stories of the Canadian Arctic. In 2008, they launched IsumaTV, a collaborative multimedia knowledge-sharing platform for Indigenous filmmakers and media organisations, and in 2012 they introduced Digital Indigenous Democracy, an innovative platform linking communities and presenting politics and legal issues within a culturally accessible framework. Based on knowledge and skill sharing, these initiatives feature stories of heritage and contemporary life. They promote interest in the land and people that contribute to the development of CES and related renewable economies through sharing with audiences and preserving for themselves the experiences of society and cultures in the North.

Isuma's films and other media projects are in oral Inuktitut, and like many AAD projects, encourage cultural preservation and resilience. This provides the community Elders with the ability to understand and appreciate the films, while strengthening the development and revitalisation of language and culture. The content on IsumaTV is accessible in over eighty languages, including Indigenous languages such as Cree, Ojibwe, and the Northern Athabaskan languages of the Na-Dene peoples. This contributes 
to the restoration of vulnerable languages which are intrinsic to cultural identity and knowledge.

To further this outreach and communication, Isuma has instituted an innovative digital service that brings media access, otherwise unavailable, to small, isolated communities in the Canadian North (Leask, 2016). Isuma productions and other creative Indigenous media activities have fostered interest, especially among northern youth, in educational and training opportunities that support these growing and economically impactful cultural initiatives, and in developing professional practices in video and film production, broadcasting, and related industries. Media education is provided by not-for-profit educational initiatives such as Wapikoni (2019) and Our World (2018) that work with local schools and hold workshops in remote Indigenous communities, encouraging youth to follow their passions while giving them practical skillsets to pursue their ambitions.

As Isuma becomes increasingly recognised in the Canadian North, it is also making an impact internationally. Isuma's Atanarjuat: The Fast Runner won Best First Feature Film at the 2001 Cannes Film Festival, and the production company has been recognised by six Genie Awards and numerous other international film awards. In 2019, the collective was selected to represent Canada in the prestigious Venice Art Biennale (Canadian Art, 2017; Sandals, 2019). In addition to the regional economic benefits of the film industry, the stories of the people who have been underrepresented and isolated from national and international conversations are now on the world stage, sharing culture and values, building resilience, and creating and strengthening international and intercultural alliances.

The changing landscape of the Arctic, a theme in many of Isuma's films, is a global topic of growing concern. For the Indigenous residents of the Canadian Arctic, this issue literally hits close to home: living off the land is not only an essential source of sustenance, but also necessary for the preservation of culture, language, and knowledge passed down from one generation to another. Isuma initiatives and the positive responses to their work demonstrate the importance of representing different knowledge systems, worldviews, and attention to cultural sensitivity within the concept of CES (Chan et al., 2012; Lepofsky et al., 2017).

\section{Lapland snow and ice design and art in Finland}

The snowy landscape has an important role to play in the local customs and traditions, identities, and cultures in the Arctic. The use of snow and ice in tourism has a long history in Finland, Lapland, and can be found in many forms, starting with snow-related sports. Snow and ice can be seen as ES and winter traditions as CES.

The concept of winter art was introduced in 2003 to describe the artistic features and phenomena related to winter aesthetics in Lapland, considering the cultural changes and opportunities related to the winter: "One manifestation 
of this change is the brisk increase in winter festivals, winter theatres, snow and ice sculpting events and snow architecture. At their best these phenomena can be called winter art" (Jokela, 2003, p. 7). Since then, art and design at the University of Lapland and the cold climate engineering department at the Lapland University of Applied Sciences have collaborated with local businesses on a project entitled Lapland Snow Design. The collaboration aimed to create new knowledge, innovations, and practices for the tourism and business sectors that utilised thinking and competence in snow and ice construction technologies (Jokela, 2014, 2019).

Long-term development brought artists, designers, and companies together in order to develop new high-quality products in cooperation with universities and businesses. At the same time, creative services based on the winter ecosystem were developed. The objective was to develop an internationally competitive product to leverage Lapland's versatile expertise of snow-related technologies and applications in the different services of the tourism industry. Different types of snow and ice environments, collaborative design methods, and marketing concepts were implemented during the project. Besides the development of new design and implementation methods for winter art, another goal was to build regional teamwork capacity and boots place-based thinking. The aim was to develop new and more efficient organisations to expand the applications of winter art in the business sector. One of the key outcomes of the project was the creation of a clustertype regional network of experts that were able to apply the products in domestic and foreign contexts. The practices were designed to be flexible, so that they could be applied in a variety of environments and tailored to meet the needs of customers in different kinds of services.

Combining tourism and the development of culture-oriented creative industries, winter art, and snow design have contributed to the creative renewable economies in Lapland. Between eight and ten large-scale snow hotels with sleeping rooms, restaurants, bars, chapels, showrooms, and so on and several smaller-scale tourism facilities are built in Lapland every year (Jokela, 2014, 2019). Compared to Sweden, where the Jukkasjärvi Ice Hotel was first built in 1990 and still remains the only ice hotel in the country, in Finland, knowledge and skill in the renewable use of snow and ice was disseminated throughout the region to improve the competence of the local people through educational, participatory, and place-based activities (Gelter \& Gelter, 2013).

\section{Crow day, sharing traditions in Siberia, Russia}

Today, the vast areas of the Russian North are turning into a complex site of conflict between Indigenous people, local non-Indigenous inhabitants, state-owned and private monopolies (extractive industries), and even tourists (Pashkevich, 2013). In order to ground the very idea of ethical and culturally sensible tourism in the environmentally and culturally fragile 
setting of the Russian Far North, the researchers and designers from the Arctic Design School (USUAA), propose a novel understanding of a tourist destination. It is a "laboratory" where innovative solutions to short-term existence in the extreme environment are generated and shaped together by tourists and local inhabitants. As global warming advances, these solutions can be further applied to facilitate adaptation to severe conditions and the development of new lifestyles for longer term visitors and non-Indigenous settlers across the Arctic regions.

In evidence for this vision, this case study presents designers' engagement with the Indigenous cultural heritage - not ignoring but learning from it, and not blindly preserving traditions but keeping them alive and available for the present and future (Nugraha, 2012). It is centered on an experiment within the AAD educational model: as a part of a master's course entitled "Regional Design" at USUAA, a student named Alexandra Nikolaeva developed a project, "A Hybrid Tradition: A designer's renewal of the traditional Crow Day," a context-sensitive adaptation of the identically named festival of the Ob Ugric people of Western Siberia. The main task was to redefine tourism as a form of mutually beneficial engagement with the land and the people, with an emphasis on inclusive participation. Seen through the CES lens, this case reveals the distinctive ability of the AAD approach to "wrap up" the protection and appreciation of the cultural and spiritual heritage into the "gift pack" of a memorable tourist experience.

Crow Day represents the end of the so-called Winter Year and the arrival of the long-awaited spring, (Golovnev, 1995). The design exploration into the context and structural elements of the celebration began with an investigation of historical materials such as publicly available collections, in-house publications, and catalogues of the archives and museums.

Diverse visual data provided insights into the complexity of human-environment interactions within the traditional culture of Northern and Arctic inhabitants. At the first stage of data analysis, the rites and ceremonies associated with the traditional Crow Day celebration were divided according to their sacredness, which determined their potential for public accessibility and tourist involvement. The three resulting groups were: (1) entirely sacred rituals that are performed by the community, for example, young girls or old women, and cannot be joined or even observed by others; (2) partly sacred rituals where spectators are allowed, but participation is restricted; and (3) open or public rituals where everyone can join the celebration. Accordingly, there were three interactive situations identified: a tourist as a participant, a deliberately invited spectator, and an occasional witness.

At the ideation stage, a cultural basis for design interpretation was proposed: to link the Northern Crow Day with the widely recognised and interculturally relevant celebration of New Year. The design outcomes included essential attributes for new and old rituals, such as a stylised New Year Tree, thematic food, a carnival with masks and costumes and a culminating ceremony of making a wish. 
In terms of practical implications, the outcomes, namely the designed objects and celebration scenarios, can contribute to shaping the region's multicultural identity by disseminating environmentally and culturally appropriate "best practices" or "know-how" that originated in the heart of the Arctic. In the long run, contextually relevant design explorations can inform the process of developing and inhabiting remote Arctic or Northern territories.

\section{A tourist memento-creating place-based sustainable souvenirs in Alaska}

Traditionally, education for tourism has been provided by tour operators, while universities teach or conduct research on tourism from a more theoretical perspective. Given the sensitivity of the Arctic environment and the speed with which it is changing, it is incumbent on Northern universities to become more involved in the process of transmitting knowledge, raising public awareness, and encouraging stewardship of the Arctic. Tourism is an ideal mechanism for this effort.

In order to encourage renewable economies, promote stewardship and raise awareness of the Arctic, a collaborative approach to provide tourism "packages" is proposed. ${ }^{1}$ These interdisciplinary solutions are needed to increase knowledge and engagement about sustainable tourism in the Arctic. A model for a designed sustainable tourism should include (1) citizenengaged environmental observation, (2) place-based sustainable art, and (3) outdoor recreation and leadership.

Citizen-engaged Environmental Observation is a type of knowledge coproduction that has received increasing interest as more people become affected in some way by Arctic environmental change (Alessa et al., 2015). Citizen science has proved to be an indispensable means of combining scientific, environmental research with education and public engagement. It has significant potential for engaging the tourism industry that provides a unique platform from which to conduct research in remote Arctic locations. Participants engaged in a sustainable tourism program are well-positioned to collect observational data on environmental change (de la Barre et al., 2016).

Place-based Sustainable Art creates artwork using local materials in the context of place and environment. As Hicks and King (2007) have observed, "Art education is well situated to address environmental problems that emerge at the point of contact between nature and social life." By creating place-based sustainable souvenirs (art), participants can become more fully engaged. Compared to purchasing imported tourist souvenir products, this creative experience promotes positive memories and a sense of deeper connection and meaning. It can be an effective methodology for systematically and purposefully developing art projects about the environment and sustainability.

Outdoor Recreation Leadership enhances the health and wellbeing of people and communities (Brymer, Cuddihy, \& Sharma-Brymer, 2012; 
Godbey, 2009; Gobster and Buchner, 2010). Outdoor recreational activities are designed to create a learning environment inspiring a passion for guardianship for our ecosystem. It focuses on life-long learning opportunities, stewardship of resources, and collaborative teamwork. A designed sustainable tourism program is fundamental to establishing this resiliency.

However, this project is an experimental "makerspace" introducing a unique approach to sustainable tourism in the Arctic_-focusing on being environmentally and culturally responsible while appreciating nature and promoting conservation. We believe that participants will build skills and knowledge in basic biological sciences, understand environmental issues and develop wilderness travel proficiencies. Making a "place-based souvenir" as a part of the sustainable tourism experience will promote a sense of appreciation for the Arctic's natural environment and play a critical role in terms of renewable economic activity in the region.

\section{Artification of the Arctic tourism and cultural revitalisation}

Through analysing the case studies and juxtaposing them with a review of the current literature, we can demonstrate some key points of potential and challenges for art and design in the development of renewable economies in the North and the Arctic.

When using CES, the creative economy has both commercial and cultural value. The AAD model, as the intersection of art and design practices with planning and production, can be used effectively when designing and producing renewable goods and creative services often connected with responsible and sustainable tourism in the North and the Arctic. We recognise that tourism in the Arctic is characterised by a process that Naukkarinen (2012) has described as artification. This refers to situations and processes in which something not originally regarded as art is transformed into something that resembles art or is influenced by artistic ways of thinking and acting. According to Naukkarinen (2012), this phenomenon can be found in business, wellness and healthcare services, and academic education and research. We argue that Arctic tourism is a scene for artification when creative and learning tourism are developed is in relation to CES and through AAD. For example, this could include nature and northern lights photography tours; wintery, snow and ice experience environments; learning tourism makerspace or slow food design production as well the revitalisation of Indigenous cultures through film productions or festivals (de la Barre, \& Broucher, 2013; Gelter \& Gelter, 2013; Jokela, 2014; Jokela et al., 2020; Leask, 2016;Urry \& Larsen, 2011).

In AAD, CES are understood not as simple products of nature that are utilised for particular economic benefits, but rather, as relational processes that people actively create and express through interactions with cultural ecosystems (Fish, Church, \& Winter, 2016). In advancing this viewpoint, AAD approximates to Chan et al.'s (2012) understanding of CES as 
experiences and capabilities that arise from human-ecosystem relationships. We argue that through creative industries like art and design, these relationships can be transformed into renewable economies.

Reports from around the world have demonstrated that creative industries generate income through trade and intellectual property rights and create new opportunities, particularly for small- and medium-sized enterprises. Even though the importance of and interdependence between creative economies and cultural services have been consistently recognised, they are often characterised as subjective and difficult to quantify in monetary terms. It is evident that their potential for future development is underestimated by national and regional decision-makers and officials responsible for regional development.

When transformed into renewable AAD products and services, CES must always contribute to the satisfaction of human needs and wants, which necessarily involves subjective considerations. Besides economic value, while being subjective, CES also benefit human capacities by facilitating knowledge, social, and cultural development and, in the Arctic case, revitalisation of local Indigenous and non-Indigenous traditions. We argue that responsible artification can take place through the development of novel renewable products and services through AAD.

\section{From artification toward Arcticfication: A risk or an opportunity}

Without involving Northern and Arctic people as collaborators, we are faced with the obvious danger of reducing Arctic ecosystems to an exotic resource that benefits external parties rather than Arctic inhabitants. While the North and the Arctic are culturally rich and diverse, Arcticfication is the tendency to present the Arctic as a cold and snowy destination devoid of human activity. Arcticfication has been reinforced by tourism marketing, as presentations of such magnificent landscapes can trigger touristic demand (Rantala et al., 2019). As Chartier (2018) has described, the phenomenon has deep roots in Western art and scholarship, where the Arctic was historically marginalised as the "Imaginary North" — as an empty and horizontal landscape rather than a multi-ethnic, multi-cultural and multi-lingual space with a rich cultural history and diverse living traditions. At the same time, Arcticfication is also the social process that has created, on the one hand, new geographical images of Northern Europe as part of the Arctic and, on the other hand, new social, economic, and political relations (Müller \& Viken, 2017). In the development and implementation of novel AAD-based renewable economic practices, Arcticfication presents an opportunity to introduce these innovations to decision-makers and into the larger social and political discussions on the future of the Arctic and the world.

Today, as insiders, many artists and designers in the Arctic have the agency to reflect and depict the transformations, nature, and culture of 
the region (Huhmarniemi \& Jokela, forthcoming, 2020). In addition, more research is being conducted on creative industries and the use of art and design in areas such as tourism, which is a growing economic field in the Arctic (Huhmarniemi \& Jokela, 2019; Huhmarniemi et al., 2021; Kugapi, Huhmarniemi \& Laivamaa, 2020; Miettinen, Sarantou \& Kuure, 2019). As our study has shown, AAD and place-based development utilising CES as an economic development strategy are particularly relevant in the North and the Arctic today. When communities, artists, and designers in remote and rural places commit to place-making as a method of economic development, the dual benefit of commercial and cultural development will stimulate the region's prosperity and well-being.

\section{Responsible utilising of CES in AAD calls creative capacity building}

Our study has shown that there are various opportunities for innovative applications of AAD in remote and peripheral areas. We agree with Petrov (2014) and Vodden et al. (2015) in arguing that innovation in the creative economy is not restricted to cities and innovation hubs only, but there are certain challenges in the Arctic. According to studies, the Arctic needs to generate more human capital by investing in its people to keep them in the region (Karlsdóttir \& Junsberg, 2015; Karlsdóttir et al., 2017; Petrov 2016, 2017). The advent of what is often referred to as the "knowledge economy" necessitates the enhancement of human skills and creativity, which will be a key to the next stage of the development process toward AAD as the creative renewable economy. This calls for novel models for educating artists and designers for the Arctic. Artists with traditional artists training may lack the will and skills to work as entrepreneurs and producers of services, or they don't have enough specific knowledge about the Arctic to apply their skill to particular northern circumstances (Huhmarniemi \& Jokela, 2019; Kugapi, Huhmarniemi \& Laivamaa, forthcoming, 2020).

We refer that as drivers of the Arctic creative economy, art and design higher education institutions and universities can lay the ground for the formation of multidisciplinary and interprofessional creative clusters, like the Arctic Design Cluster in Rovaniemi, Lapland. The cluster is built around the research and education of the Faculty of Art and Design to boost the regional economy by implementing processes where art, design, creative services, and CES are combined with place-making to exploit existing strengths of the region.

\section{Conclusion}

Through the case studies and literature review, this chapter has filled the notable gap in the research connected to art, design, and CES. We argue that identifying, analysing, and using CES as the potential for creative renewable industries; particularly AAD can play an important role in 
the future of the Arctic in terms of sustainable economy. Merging CES and $\mathrm{AAD}$ with a place-making strategy is a way to exploit the existing strengths of communities to create renewable economies in the rural and remote areas of the Arctic.

As our study has demonstrated, there is no single way to implement the CES approach in the creative economy and art and design. Implementation necessarily depends on local, regional, social and cultural conditions. As the concept of CES is subjective and always linked to society and culture, it is necessary to understand the specific conditions they are operating in. Both identified trends: Artification of Arctic tourism and cultural revitalisation practices and Arcticfication as a risk or an opportunity for AAD should be recognised and utilised in responsible way when implementing CES in creative renewable economy in the Arctic. Therefore, art and design as renewable economies must be implemented through culturally sensitive and place-based strategies to respond to the challenges and ensure sustainability in the North and the Arctic. Higher art and design education have an important role to secure creative human capacity and promotion of sustainable future in Arctic.

\section{Note}

1. The concept is co-developed by Audrey Taylor, Ph.D., Assistant Professor of Environmental Studies, Department of Geography and Environmental Studies; Herminia Din, Ph.D., Professor of Art Education, Department of Art; and Timothy Miller, Director, Department of Health, Physical Education and Recreation at the University of Alaska Anchorage.

\section{References}

Alessa, L., Kliskey, A., Pulsifer, P., Griffith, D., Williams, P., Druckenmiller, M. ... Jackson, L. (2015). Best practices for community-based observing: a national workshop report. Arctic Observing Summit. http:/www.arcticobservingsummit.org/ sites/arcticobservingsummit.org/files/Alessa $\% 20$ et $\% 20 \mathrm{al} \% 20-\% 20$ CBONReport_ DRAFT\%20FINAL-updated-2016-03-07.pdf

ASAD. (2019). Arctic sustainable arts and design thematic network. ASAD Network. http://www.asadnetwork.org/

de la Barre, S., \& Broucher, P. (2013). Consuming stories: Placing food in the Arctic tourism experience. Journal of Heritage Tourism, 8(2-3), 37-41.

de la Barre, S., Maher, P., Dawson, J., Hillmer-Pegram, K., Huijbens, E., Lamers, M. ... Stewart, E. (2016). Tourism and Arctic observation systems: Exploring the relationships. Polar Research, 35(1), 24980.

Big River Analytics. (2017). Impact of the Inuit Arts economy. Indigenous and Northern Affairs Canada, Government of Canada. https://www.rcaanc-cirnac. gc.ca/eng/1499360279403/1534786167549

Brymer, E., Cuddihy, T. F., \& Sharma-Brymer, V. (2012). The role of nature-based experiences in the development and maintenance of wellness. Asia-Pacific Journal of Health, Sport and Physical Education, 1(2), 21-27. doi: https://doi.org/10.1080/1 8377122.2010.9730328. 
Canadian Art. (2017, December 13). Inuit Art Collective Isuma to Represent Canada at 2019 Venice Biennale. Canadian Art. https://canadianart.ca/news/ isuma-venice-biennale-canada-pavilion-2019

Chan, K., Satterfield, T., \& Goldstein, J. (2012). Rethinking ecosystem services to better address and navigate cultural values. Ecological Economics, 74, 8-18.

Chartier, D. (2018). What is the "Imagined North"? Presses de l'Université du Québec.

Cooper, N., Bardy, E., Steen, H., \& Bryce, R. (2016). Aesthetic and spiritual values of ecosystems: Recognising the ontological and axiological plurality of cultural ecosystem "services”. Ecosystem Services, 21(B), 218-229. doi: http://dx.doi. org/10.1016/j.ecoser.2016.07.014.

Daniel, T. C., Muhar, A., Arnberger, A., Aznar, O., Boyd, J. W., Chan, K. M. A. ... von der Dunk, A. (2012). Contributions of cultural services to the ecosystem services agenda. Proceedings of the National Academy of Sciences, 109(23), 8812-8819. doi: http://dx.doi.org/10.1073/pnas.1114773109.

Daniels, J., Baldacchino, G., \& Vodden, R. (2015). Matters of place: The making of place and identy. In K. Vodden, R, Gibson, \& G. Baldacchino (Eds.), Place peripheral: Place-based development in rural, island, and remote regions (pp. 23-40). ISER Books.

Fish, R., Church, A., \& Winter, M. (2016). Conceptualising cultural ecosystem services: A novel framework for research and critical engagement. Ecosystem Services, 21(B), 208-217. doi: https://doi.org/10.1016/j.ecoser.2016.09.002.

Fondahl, G., \& Wilson, G. N. (Eds.). (2017). Northern Sustainabilities: Understanding and addressing change in the circumpolar world. Springer Nature.

Fullerton, C. (2015). Arts, culture, and rural community economic development: A Southern Saskatchewan case study. In K. Vodden, R, Gibson, \& G. Baldacchino (Eds.), Place peripheral: Place-based development in rural, island, and remote regions (pp. 180-210). ISER Books.

Gad, U., Jacobsen, M., \& Strandsbjerg, J. (2019). Introduction: Sustainability as a political concept in the Arctic. In. U. P. Gad \& J. Strandsbjerg (Eds.), The politics of sustainability in the Arctic: Reconfiguring identity, space and time (pp. 1-18). Routledge.

Gelter, H., \& Gelter, J. (2013). An innovation lost. The Ice Dome Concert Hall Project in Piteå. In L. Lindeborg, \& L. Lindkvist (Eds), The value of arts and culture for regional development: A Scandinavian perspective (pp. 252-266). Routledge.

Giacometti, A., \& Teräs, J. (2019). Regional economic and social resilience: An exploratory in-depth study in the Nordic countries. Nordregio. doi: http://dx.doi. org/10.6027/R2019:2.1403-2503

Gobster, P. H., \& Buchner, D. M. (2010). Healthy outdoor recreation: An integrated approach to linking physical activity with wellness goals. In L. Payne, B. Ainsworth, \& G. Godbey (Eds.), Leisure, health and wellness: Making the connections (pp. 437-446). Venture Publishing.

Godbey, G. (2009). Outdoor recreation, health, and wellness: Understanding and enhancing the relationship. RFF Discussion Paper No. 09-21. doi: http://dx.doi. org/10.2139/ssrn.1408694

Golovnev, A. V. (1995). Govoryashhie kul'tury [Talking cultures]. URO RAN.

Griffith, D. (2014). Imagining natural Scotland. Creative Scotland Publications

Guttorm, G. (2015) Contemporary Duodji-A personal experience in understanding traditions. In Jokela T. and Coutts G. (Eds.), Relate North: Art, heritage and identity, (pp. 60-77). Lapland University Press. 
Hesmondhalgh, D. (2007). The cultural industries (2nd ed.). SAGE Publications.

Hearnshaw, E., \& Cullen, R. (2010, August 26-27). The sustainability and costeffectiveness of water storage projects on Canterbury rivers: the Opihi River case paper [Paper presentation]. The NZARES Conference, Nelson, New Zealand.

Hicks, L. E., \& King, R. J. H. (2007). Confronting environmental collapse: Visual culture, art education, and environmental responsibility. Studies in Art Education, 48(4), 332-335.

Howkins, J. (2001). The creative economy: How people make money from ideas. Penguin.

Huhmarniemi, M., \& Jokela, T. (2019). Environmental art for tourism in the Arctic: From handicraft to integrated art and reform on artists' skills. Synnyt/ Origins, 1(2019), 63-80. https://wiki.aalto.fi/pages/viewpage.action?pageId= 151504259

Huhmarniemi, M. \& Jokela T. (2020). Arctic arts with pride: discourses on Arctic arts, culture and sustainability. Sustainability 12(2), 604. https://doi.org/10.3390/ su12020604

Huhmarniemi, M.; Kugapi, O.; Miettinen, S. \& Laivamaa, L. (2021). Sustainable Future for Creative Tourism in Lapland. In N. Duxbury; S. Albino \& C. Pato Carvalho (eds.), Creative Tourism: Activating Cultural Resources and Engaging Creative Travellers (pp. 239-253). Cabi International.

Härkönen, E., Huhmarniemi, M., \& Jokela, T. (2018). Crafting sustainability. Handcraft in contemporary art and cultural sustainability in Lapland. Sustainability, 10(6). doi: https://doi.org/10.3390/su10061907

Härkönen, E., \& Vuontisjärvi, H. (2018). Arctic art \& design education and cultural sustainability in Finnish Lapland. In T. Jokela \& G. Coutts (Eds.), Relate North: Practising place, heritage, art \& design for creative communities (pp. 86-105). Lapland University Press.

Hølleland, H., Skrede, J., \& Holmgaard, S. (2017). Cultural heritage and ecosystem services: A literature review. Conservation and Management of Archaeological Sites, 19(3), 210-237.

Jokela, T. (2003) Introduction. In H. Huhmarniemi, T. Jokela \& S. Vuorjoki, S. (Eds.), winter art. Statement on winter art and snow construction (6-11). University of Lapland.

Jokela, T. (2013). Engaged art in the North: Aims, methods, contexts. In T. Jokela, G. Coutts, M. Huhmarniemi, \& E. Härkönen (Eds.), Cool: Applied visual arts in the North (pp. 10-21). University of Lapland.

Jokela, T. (2014). Snow and ice design innovation in Lapland. In E. Härkönen, T. Jokela, \& A. J. Yliharju (Eds.), Snow design in Lapland: Initiating cooperation (pp. 180-181). University of Lapland.

Jokela, T. (2017) Art, design, and craft interwoven with the North and the Arctic. In M. Huhmarniemi, A. Jónsdóttir, G. Guttorm, \& H. Hauen, (Eds.), Interwoven (pp. 4-11). University of Lapland.

Jokela, T. (2019). Arts-based action research in the north. In Oxford Research encyclopedia of education. Oxford University Press.

Jokela, T., \& Coutts, G. (Eds.). (2018a). Relate North: Art and design education for sustainability. Lapland University Press.

Jokela, T., \& Coutts, G. (2018b) The North and the Arctic: A laboratory of art and design education for sustainability. In T. Jokela \& G. Coutts (Eds.), Relate North: Art and design education for sustainability (pp. 98-117). Lapland University Press. 
Jokela, T., Coutts, G., Huhmarniemi, M., \& Härkönen, E. (Eds.). (2013). Cool. Applied Visual Arts in the North. Publications of the Faculty of Art and Design of the University of Lapland C 41. http://urn.fi/URN:ISBN:978-952-484-638-7

Jokela, T., Huhmarniemi, M., \& Hautala-Hirvioja, T. (2019). Preface. Synnyt 1/2019 special issue on Arctic Arts Summit, 6-12. https://wiki.aalto.fi/pages/viewpage. action?pageId=151504259

Jokela, T., Huhmarniemi, M., \& Paasovaara, J. (Eds.). (2020). Soveltava taide ja luontokuvaus. [Applied visual art and nature photography]. Lapland University.

Jokela, T., \& Tahkokallio, P. (2015). Arctic design week: A forum and a catalyst. In T. Jokela \& G. Coutts (Eds.), Relate North: Art, heritage \& identity (pp. 118-139). Lapland University Press.

Joy, F. (2019). Sámi cultural heritage and tourism in Finland. In M. Tennberg, H. Lempinen, \& S. Pirnes (Eds.), Resources, social and cultural sustainabilities in the Arctic (pp. 144-162). Routledge.

Karlsdóttir, A., \& Junsberg, L. (Eds.). (2015). Nordic Arctic youth future perspectives. Nordregio.

Karlsdóttir, A., Olsen, L., Harbo, L., Jungsberg, L., \& Rasmussen, O. (2017). Future regional development policy for the Nordic Arctic: Foresight analysis 2013-2016. Nordregio.

Kugapi, O., Huhmarniemi, M. \& Laivamaa, L. (2020). A Potential treasure for tourism: Crafts as employment and a cultural experience service in the Nordic North. In A Walmsley, K. Åberg, P. Blinnikka, G.T. Jóhannesson, G.T. (eds.), Tourism Employment in Nordic countries: Trends, practices, and opportunities (pp. 77-99). Palgrave Macmillan.

Kramvig, B., \& Flemmen, A. B. (2019). Turbulent indigenous objects: Controversies around cultural appropriation and recognition of difference. Journal of Material Culture, 24(1), 64-82.

Kunuk, Z. (2019.). Zacharias Kunuk. Isuma. https://www.isuma.tv/members/ zacharias-kunuk

Landry, C., \& Bianchini, F. (1995). The Creative City. Demos.

Leask, J. (2016). IsumaTV Builds Innovative Digital Systems to Share High-Def Streaming Video in Low Speed Remote Communities. First Mile. https://firstmile.ca/ isumatv-builds-innovative-digital-infrastructure-to-share-high-def-streamingvideo-in-remote-communities

Lepofsky, D., Armstrong, C. G., Greening, S., Jackley, J., Carpenter, J., Guernsey, B. ... Turner, N. J. (2017). Historical ecology of cultural keystone places of the northwest coast. American Anthropologist, 119(3), 448-463. doi: https://doi. org/10.1111/aman.12893.

Lindhjem, H., Reinvang, R., \& Zandersen, M. (2015). Landscape experience as a cultural ecosystem service in a Nordic context: Concepts, values and decicion-making. TemaNord, 2015, 547. doi: http://dx.doi.org/10.6027/TN2015-549

Miettinen, S., Sarantou, M., \& Kuure, E. (2019). Design for care in the peripheries: Arts-based research as an empowering process with communities. NORDES Nordic Design Research, 8. https://archive.nordes.org/index.php/n13/article/view/467

Milcu, A. I., Hanspach, J., Abson, D., \& Fischer, J. (2013). Cultural ecosystem services: A literature review and prospects for future research. Ecology and Society, 18(3), 44. Millennium Ecosystem Assessment. (2005). Ecosystems and human well-being: Synthesis. Island Press. http://www.millenniumassessment.org/documents/document. 356.aspx.pdf 
Milone, P., \& Ventura, F. (Eds.). (2010). Networking the rural: The future of green regions of Europe. Van Gorcum.

Minnakhmetova, R., Usenyuk-Kravchuk, S., \& Konkova, Y. (2019). A contextsensitive approach to the use of traditional ornament in contemporary design practice. Synnyt/origins, Special issue on Arctic Arts Summit 1, 49-62. https:// wiki.aalto.fi/pages/viewpage.action?pageId=151504259

Müller, D. K., \& Viken, A. (2017). Toward a de-essentializing of indigenous tourism? In A. Viken \& D. K. Müller (Eds.), Tourism and indigeneity in the Arctic (pp. 281-289). Channel View.

Mäkikalli, M., Holt, Y., \& Hautala-Hirvioja, T. (Eds.). (2019). North As a meaning in design and art. Lapland University Press.

Naukkarinen, O., (2012) Variations on artification. Contemporary Aesthetics, Special Volume 4 (2012) ARTIFICATION. https://digitalcommons.risd.edu/cgi/ viewcontent.cgi?article $=1189 \&$ context=liberalarts_contempaesthetics

Nordic Council of Ministers. (2011). Megatrends. TemaNord, 2011, 527. http:// norden.diva-portal.org/smash/get/diva2:702166/FULLTEXT01.pdf

Nordic Councils of Ministers. (2018). Arctic business analysis: Creative and cultural industries. Nordisk Ministerråd. doi: http://dx.doi.org/10.6027/ANP2018-708

Nugraha, A. (2012). Transforming tradition. Unigrafia Aalto University.

Olsen, L., Berlina, A., Jungsberg, L., Mikkola, N., Roto, J., Rasmussen, R., \& Karlsdottìr, A. (2016). Sustainable business development in the Nordic Arctic [Nordregio working paper 2016: 1]. Nordregio.

Olsen, K. O., Abildgaard, M. S., Brattland, C., Chimirri, D., de Bernardi, C., Edmonds, J. ... Viken, A. (2019). Looking at Arctic tourism through the lens of cultural sensitivity. ARCTISEN - A transnational baseline report. University of Lapland.

Our World. (2018). Our World: Youth, Film, Culture. https://www.ourworldlanguage.ca/

Pashkevich, A. (2013). Tourism development planning and product development in the context of Russian Arctic territories. In R. H. Lemelin, P. T. Maher, \& D. Ligget (Eds.), From talk to action: How tourism is changing the polar regions (pp. 41-60). Lakehead University.

Petrov, A. N. (2014). Creative Arctic: Towards measuring Arctic's creative capital. In L. Heininen, H. Exner-Pirot, \& J. Plouffe (Eds.), Arctic yearbook 2014: Human capital in the North (pp. 149-166). Northern Research Forum.

Petrov, A. N. (2016). Exploring the Arctic's "other economies": Knowledge, creativity and the new frontier. The Polar Journal, 6(1), 51-68.

Petrov, A. N. (2017). Human capital and sustainbale development in the Arctic: Towards intellectual and empirical framing. In G. Fondalh \& G. N. Wilson (Eds.), Northern Sustainabilities: Understanding and addressing change in the circumpolar world. Springer.

Rantala, O., de la Barre, S., Granås, B., Pór Jóhannesson, G., Müller, D. K., Saarinen, J. ... Niskala, M. (2019). Arctic Tourism in Times of Change: Seasonality. Tema Nord. http://norden.diva-portal.org/smash/get/ diva2:1312957/FULLTEXT01.pdf

Sandals, L. (2019). Zacharias Kunuk Speaks on Isuma's Venice Biennale Project. Canadian Art. https://canadianart.ca/news/zacharias-kunuk-speaks-on-isumasvenice-biennale-project

Schilar, H., \& Keskitalo, E. C. (2018). Ethnic boundaries and boundary-making in handicrafts: Examples from northern Norway, Sweden and Finland. Acta Borealia, 35, 29-48. 
Schott, S. (2016). The changing face of economic development in the Canadian North. Open Canada. https://www.opencanada.org/features/changing-faceeconomic-development-canadian-north

Smith, L. T. (1999). Decolonizing methodologies: Research and indigenous peoples. Zed Books.

Soini, K., \& Birkeland, I. (2014). Exploring the scientific discourse on cultural sustainability. Geoforum, 51, 213-223.

Stålhammar, S. S., \& Pedersen, E. (2017). Recreational cultural ecosystem services: How do people describe the value? Ecosystem Services, 26(Part A), 1-9. doi: https://doi.org/10.1016/j.ecoser.2017.05.010.

Tennberg, M., Lempinen, H., \& Pirnes, S. (Eds.). (2019). Resources, social and cultural sustainabilities in the Arctic. Routledge.

Teräs, J., Lindberg, G., Johnsen, I. H. G., Perjo, L., \& Giacometti, A. (2014). Bioeconomy in the Nordic region: Regional case studies. Nordregio.

Stephen, K. (2018). Societal impacts of a rapidly changing Arctic. Current Climate Change Reports, 4, 223-237.

Urry, J., \& Larsen, J. (2011). The tourist gaze 3.0. Sage.

United Nations Conference on Trade and Development (UNCTAD). (2018). Creative economy outlook: Trends in international trade in creative industries. UNCTAD. https://unctad.org/en/pages/PublicationWebflyer.aspx?publicationid=2328

University of the Arctic. (2019). Thematic Networks and Institutes. University of the Arctic. http://www.uarctic.org/organization/thematic-networks/

Wapikoni. (2019). Mission, Values, and Objectives. Wapikoni. http://www.wapikoni. ca/about/who-are-we/mission-values-and-objectives

Vodden, K., Gibson, R., \& Baldacchino, G. (Eds.). (2015). Place peripheral: Placebased development in rural, island, and remote regions. ISER Books.

Woien, M., Kristensen, I., \& Teräs, J. (2019). The status, characteristics and potential of smart specialisation in Nordic regions. Nordregio Report, 2019, 3. 